\title{
Bringing Local Knowledge into Program Implementation Process (Case Study of PIJAR Program)
}

\author{
Fatin Nuha Astini ${ }^{1}$, Anang Dwi Santoso 2 , Oscar Radyan Danar 3 Junior Researcher, \\ Smeru Research Institute, , Departement of Public Policy and Management, FISIPOL, UGM, \\ Departement of Public Administration, FIA, Universitas Brawijaya \\ 1 fastini@smeru.or.id, $_{2}^{2}$ anang.dwi.santoso@mail.ugm.ac.id, ${ }^{3}$ oscar@ub.ac.id.
}

Keywords: local knowledge, local economic development, and program implementation

\begin{abstract}
Currently, local knowledge is an important consideration for practitioners and public policy academics. Some parties argued that the failure of program implementation was caused by the fact that policy did not pay attention to the reality of society and tended to make the community as a passive target group. This study aimed to illustrate the importance of including local knowledge in program implementation, especially program for local economic development. This research was a case study on PIJAR Program in Dompu Regency, West Nusa Tenggara Province. Researchers argued that local knowledge became an inseparable part in the implementation of the program and public policy in order to improve the welfare of the community. The data in this study was taken through the process of interviewing the community and related agencies, and observation. The results showed that considering local knowledge would improve program effectiveness due to (1) recognition that local communities were active in implementing programs that accommodate local knowledge and context; (2) local knowledge as an inseparable part of the community; (3) awareness of the development of local potentials owned by communities, local governments and private sectors. This research is expected to be useful for practitioners and academics to make the knowledge of local people as part of the values that must be included in every process of program implementation.
\end{abstract}

\section{INTRODUCTION}

This paper aimed to illustrate the integration of local knowledge to the policy implementation in Indonesia. Contrary to the previous studies on the implementation of public policy in Indonesia which were more top-down and technocratic (Suwarno et al., 2018; Jodoin, 2017; Pratomo, 2017), this article tried to give another review on values of local community which may be included in policy implementation. This paper also emphasized that local knowledge was significant to the public policies in Indonesia which had not been widely discussed in the past. Generally, local knowledge defines as an inherent knowledge in a certain territory ( $\mathrm{Li}$, Easterby-Smith, Lyles, \& Clark, 2016).

The concept of policy implementation had three generations of top-down, bottom-up, and hybrid theories (Puzl and Treib, 2007). The first generation was top-down, emphasized the capability of decision makers to produce unequivocal policy objectives and control each stages of policy implementation. The following generation was bottom-up, generated from critism of the first generation which put bureaucrats as the main actors in policy implementation. This generation regarded the network of policy implementors by including public as part of the 
network. Meanwhile, the third generation tried to incorporate both ideas of the previous generations.

This study established from the concept of third generation policy implementation which tried to incorporate the implementation of bottom-up and top-down policies. According to its followers, this concept tried to integrate central steering and local autonomy (Puzl and Treib, 2007). Technically, this third generation tried to bring the inherent cultural aspects in community into the strategy of policy implementation. This generation argued that by including local knowledge, the policy will be more successfully implemented.

Local knowledge generally defined as an inherent knowledge in a particular territory (Li et al., 2016). Van der Ploeg (1993) added that local knowledge evidence might be originated from traditions, intuitions, imaginations, images, local stories and narratives, and also visual demonstration such as street theater. By taking local knowledge into policy consideration, acceptance and community participation towards the policy will increase (Jatanasaulwong, 2017). Thus, the objectives of policy will be achieved easily.

By taking the case of PIJAR program, this study presented an overview of the implementation of the third generation policy which attempted to incorporate the first generation (top-down) and second generation (bottom-up). PIJAR program was a program of local economic development through potentials optimization of leading areas/sectors such as was cows, corn, and seaweed, which was initiated by the West Nusa Tenggara's Governor, TGH M. Zainul Majdi. This policy tried to integrate community local knowledges into the process of policy implementation. This policy has been implemented in all of Regencies and Cities in West Nusa Tenggara province. However, only in Dompu Regency this policy was successfully implemented. By integrated the local knowledge of West Nusa Tenggara community, this policy was able to improve the crops (BPS Dompu Regency, 2018). This research argued that the successful implementation of PIJAR program was the result of Dompu's government integrated the PIJAR program with the community local knowledge.

This policy recognized the local knowledge of Dompu's farmers on ecology and agriculture which was obtained from their ancestors over time. This local knowledge was in the form of farming and gardening experiences and also interaction with environment. Although this knowledge continued to diminish, Dompu's people still held the local knowledge as a consideration of decision making in managing the land and livestocks. The reciding local knowledge was caused by the emergence of new knowledge as a consequence of various agriculture counseling. As a consequence, Dompu's people needed to balance these various knowledges. However, Dompu's farmers did not necessarily receive all the knowledge they got from the agricultural counselings. These farmers still had room to manage their natural resources because they were more familiar with the condition of their agricultural environment.

The result of PIJAR policy was the improvement of community economic growth of $4.6 \%$ in 2010 (RKPD 2013 Dompu Regency, 2012). This document also stated there was a 300\% increasing of maize production. Dompu Regency's GDRP in 2010 increased by $12.35 \%$ from 2008. 
This paper consists of several parts. This paper begins with a background which briefly describes the subject matter as the reason of this paper writing. Furthermore, the author will discuss the implementation concept of third generation theory and local knowledge as the theoritical basis. After that, the author will describe the research method followed by the findings and discussion. The last part of this paper consists of conclusion and study limitations.

\section{LITERATURE REVIEW}

\section{The Implementation of Third Generation Theory}

Study of public policy implementation is divided into three generations (Puzl and Treib, 2007). The first generation is represented by Pressman and Wildasky study which emphasizes the capability of decision maker to generate unequivocal policy objectives and control each stages of policy implementation. The following generation is bottom-up which is generated from first generation critism which puts bureaucrats as the main actors in policy implementation. This generation regards the network of policy implementors by including public as part of the network. This generation disciples are Carl Van horn and Donald van Meter and also Daniel Mazmanian and Paul Sabatier. Meanwhile, the third generation tries to incorporate both ideas of the previous generations. A brief explanation of this review can be seen in Table 1.

Table 1. Top-Down and Bottom-Up Theories Comparison

\begin{tabular}{|l|l|l|}
\hline & Top-down theories & Bottom-up theories \\
\hline Research strategy & $\begin{array}{l}\text { From political to } \\
\text { administrative excecution }\end{array}$ & $\begin{array}{l}\text { From individual bureaucrats } \\
\text { to administrative networks }\end{array}$ \\
\hline Goal of analysis & $\begin{array}{l}\text { Prediction/policy } \\
\text { recommendation }\end{array}$ & Description/explanation \\
\hline Model of policy process & Stagist problem \\
\hline $\begin{array}{l}\text { Character of implementation } \\
\text { process }\end{array}$ & Hierarchical guidance & $\begin{array}{l}\text { Decentralized } \\
\text { solfing }\end{array}$ \\
\hline $\begin{array}{l}\text { Underlying model of } \\
\text { democracy }\end{array}$ & Participation \\
\hline
\end{tabular}

Source: Puzl and Treib (2007)

The third generation was born in the 1990s, originally developed by Goggin et al (1990). This generation introduced the idea that behavioral variable of policy implementing actors determined the success of policy implementation. At the same time, there was also a contingency or situational approach that emphasized the adaptation of policy implementation depending on the situation and condition in the field. The third generation emerged after a long debate with no agreement as the result. This concept was a mediator or alternative to the two previous theories.s moreover, this concept based on measurable and rational indicators to analyze the policy implementation issues.

\section{Local Knowledge in Program Implementation}

Local knowledge generally defined as an inherent knowledge in a particular territory (Li et al., 2016). Furthermore, Giordano et al., (2010) defined the local knowledge as a group of 
knowledge that came from a specific group of people. Other expert defined local knowledge as a non-scientific knowledge based on local wisdom, experience, and practice adapted from local ecosystem (Ballard et al., 2008). This knowledge consisted of explicit information up to the implicit information in a particular society. Peets and Brooks (2006) stated that this knowledge originated from the interaction of local community and its environment resulted in an experience that then formed the locl knowledge. Specifically, Corburn (2003) stated that local knowledge consisted of informations related to context and local setting including the knowledge of characteristics, circumtances, events, and relationships and also people's comprehension of these things.

Public policy scientists described local knowledge as a knowledge derived from common sense, casual empiricism, thoughtful speculation, and analysis (Lindblom and Cohen, 1979: 12). Local knowledge became an important element of policy especially when local community were involved in the policy (Jatanasaulwong, 2017). In accordance with that opinion, Lawton and Maculay (2014) stated that the success of the policy was also dtermined by the public's understanding of a policy. To achieve this, community participation needed to be conducted on issues identifying to policy proposals.

Jatanasaulwong (2017) in a study of local knowledge in Thailand found that policies to reduce the numbers of intoxicated people and gamblers, the utilization of local knowledge effectively reduced the number of gamblers and drunkards. In this policy, to increase the people happiness in Thailand, the utilization of local knowledge evidently increasing the happiness in community. In the natural disaster sector, the government introduced community-based disaster governance which was able to reduce the impact of natural disasters as the policy regarded the social and cultural conditions of the community.

In another study, Nita et al (2018) found that incorporating local knowledge in a green city program planning in Romania could increase community participation and quality of policy. In addition, the level of policy acceptance also increased due to community involvement. Audefroy and Sanchez (2017) stated that by regarding the local knowledge, community resilience to climate change disasters would increase in Mexico.

\section{RESEARCH METHOD}

This research was a qualitative research with case study approach. This reserach tried to compile local knowledged by inventorying informations of farmer local knowledge. The data in this research was taken from a longitudinal study with the title of Social Impact of Road improvement in Dompu Regency, West Nusa Tenggara. To support the findings in the primaary data, researchers also used secondary data. Secondary data in this research included RKPD and BPS data of Dompu Regency. The data were compiled, selected, reduced, and synthesized based on the informations obtained.

\section{GENERAL OVERVIEW OF PIJAR}

\section{PROGRAM Early Period}

PIJAR program was a program of local economic development through the optimization of potential areas/leading sectors of cows, corn, and seaweed initiated by the Governor of West 
Nusa Tenggara 2009-2013 period, TGH M. Zainul Majdi. These three comodity selection was based on several considerations, including (i) the land condition of the province which in the form of dry land (utilizing unused land), (ii) regional agroclimate conditions met the requirements of maize cultivation, such as tropical climate, gromosol soil type, and topography of ramps to bumpy, (iii) from the society aspect, generally the community accustomed to farming, livestock breeding, and seaweed cultivation. One of the regencies that positively supported PIJAR program was Dompu regency. (See Table 2) Through PIJAR program with cross-sectoral cooperation (Regional Secretary, Department of Agriculture, and Food Security Department), the local government provided seeds of corn, seaweed, and cows to communities incorporated farmer groups. Assistance was provided through farmer groups with support from extension field workers (PPL), so that the process and effectiveness of PIJAR implementation could be monitored. Along with the success of corn harvest in the beginning of PIJAR program, people who didn't join the farmer group started to grow corn independently without waiting for help from the government.

The success of PIJAR was also supported by the establishment of PT Seger Agro Nusantara warehouse branch in 2008 in Sumbawa. In the same year, the company branch was also established in Dompu. The corn in Dompu Regency was then sent to Surabaya and exported to the Philippines. With the existence of this company, the corn farmers didn't find diffculty to sell their crops. Generally, corn farmers in Dompu prefered to sell their crops to the Sumbawa warehouse than in Dompu due to the purchasing money was given in cash.

In the earlier years of PIJAR program, the corn price was still low and rarely experiencing price increases. However, due to a visible new income from the corn sector, more people started to cultivate corn. During President Jokowi's visit to Dompu, he listened to the complaints of corn farmers (April 2015). Based on the great potential of corn in Dompu, several months after president visit, the Ministry of Trade issued a ministerial regulation (Permendag) No. 21 year 2016 about The Stabilization of Corn Reference Price at Farmer Level anf Permendag No. 63 year 2016 about the Purchase Reference Price at Farmers and Reference Price for Consumers1. Since then the welfare of corn farmers increased along with the certainty of corn prices.

\section{Continuation Period}

In the second period of Governor leadership of TGH M. Zainul Majdi (2013-2018), he began to focus on industrialization of PIJAR's leading processing sector such as cow, corn, and seaweed. It was expected that this industrialization provided more values to the community, especially farmers. However, during this research, the echo of PIJAR product's addition value was not visible yet.

Among the three comodities, corn was more superior than seaweed and cow. It occured due to higher dependency of seaweed towards the weather and until now there was no method to reduce the dependence. Often seed giving was fruitless due to crop failure caused by bad weather. As for cows, people tended to raise cattle as a mean for savings. 


\section{DISCUSSION}

\section{Local Knowledge}

Local knowledge of farmer was a practice of farming derived from hereditary experiences. Here were some local knowledge collected by the researcher: To forecast the nature of annual rainfall, Farmers in Dompu Regency conducted a calculations based on the Tumbuk event by looking at the sun position above the head at $12.00 \mathrm{pm}$.

In the Christian calendar, Tumbuk always occured on 12-16 October. Tumbuk was used as socieety foundation to determine the first rain fall. According to the community, on the 6th there would be a heavy rain. It would take place until Februari 16th. On that day, it would be a normal intensity of rain. Then, starting on 26th, the intensity of rain fall would decrease.

\section{Balancing Local Knowledge: The Roles of Professional Knowledge}

Climate change causing a chaos in agricultural dating system. Starting in 2015, the rain no longer fell differed from people's predictions. This occurence encouraged the government to provide knowledge to the community about climate change and its adaptation strategy through agricultural counseling activities.

In 2015, the government introduced agrometeorology to measure rainfalls, a simple agroecosystem observation. This activities included monthly meetings, discussion of seasonal scenarios, and crops evaluation. Rainfall measurement activities were conducted to measure the rainfall level every day in a device placed on the ground. The activities of agroecosystem observation focused on learning how to handle pest attack.

Monthly meetings were conducted to balance out the local knowledge and professional knowledge. Knowledge elaboration between community and professional was delivered through agricultural counseling workers in these meetings. Counselors and farmers were discussing each new problems arised from climate change.

\section{Integration of Local Knowledge in PIJAR Program Implementation}

Program implementation of economic development based on local knowledge through PIJAR program can be viewed on various aspects of superior comodity selection, product development and other supports. The descriptions of each findings are:

\section{Superior Products Selection in PIJAR Program}

Cow selection as a leading commodity based on various considerations, (i) historically and culturally, raising cow was a tradition of West Nusa Tenggara community. It had been a long time West Nusa Tenggara becoming a cattle supplier to various regions in Indonesia. (ii) land and forage potential. Cattle system in West Nusa Tenggar consisted of off cage system for the Sumbawa island and collective cage system in Lombok island.

Prior to the start of PIJAR program, in 2009 West Nusa Tenggara province launched a program of a million cows homeland (bumi sejuta sapi/BSS). BSS aimed to improve the human resources capacity and breeders institutional and also collective cages, establish 
integrated cattle farming with related sectors, optimize the utilization of livestock pastures. These objectives were expected to accelerate the Achievement of National Beef SelfSufficiency (P2SDS), and to improve the cattle farmers-ranchers' income.

The implementation strategy of BSS Program was in the form of increasing population and productivity of cows with "3-O" (One Cow, One Calf, One Year), seddlings control, productive cattle slaughtering and cow disease control, spatial management of livestock herding, development of forage technology, human resources and institutional development through livestock counseling, development of farmer breeder groups, and facilities and infrastructure development.

After encouraging cattle as a leading commodity, the provincial government added 2 commodities to be developed, corn and seaweed. Both commodities joined cattle to be in PIJAR program. Selecting corn as superior commodity based on (i) considering land condition of West Nusa Tenggara province which majority of dry land (utilizing unused land), (ii) regional agroclimate conditions met the requirements of corn cultivation such as tropical climate, gromosol soil type, and ramps to bumpy topography, (iii) from the society aspect, generally the community accustomed to corn cultivation, as well as determining seaweed as a superior commodity. The regional waters of West Nusa Tenggara was extensive and the community had been doing seaweed cultivation for a long time.

Both programs were the governor's initiation which was implemented through cross-sectoral cooperation between the Regional Secretary, Department of Agriculture, and Food Security Deaprtment. At the development stage, the community was not involved but the program was able to see the potentials to activate local traditions in order to improve the economy.

\section{PIJAR Program Development}

The implementation of PIJAR program began in 2010 involving various related agencies, (i) the Regional Secretary played a role in coordinating cross-sectoral cooperation in the development of leading commodities, (ii) Fisheries and Marine Department, Agriculture Department, and Livestock Offices played a role in technical and regulation of program achievement such as facilities and infrastructures assistance, seeds provision, capacity building for farmers through socialization and assistance activities by agriculture counselors, (iii) Food Security Department, (iii) Industry and Trade Office. At the end of 2010, SATLAK (Implementation Task force ) was formed, a combination of several components: apparatus, counselors, NGOs, and Indonesian National Army. All of them worked together to socialaize the program.

The development of cow commodities was part of the Livestock Offices. At the beginning of program implementation, the government gave cows to almost all poor villages through farmer groups. These groups were submitting proposals to government to receive the cows. Type of given cows was Dompu cow or Sumbawa cow with height of 102-105 cm, and aged 2-2.5 years. After proposal submitting, the Livestock offices verified Receiver Candidate Location Candidate (Calon Penerima Calon Lokasi/CPCL) by direct visiting to the location, cage checking, verifying the data of the receiver, and monitoring the cattle managed by the groups. The verification results 
were submitted to the Province Livestock Office. The final decision was in the hand of Province Livestock Office. This process was conducted from 2010-2013.

In addition to cow, in 2012 there was a program of productive cows rescue with incentives provision (some money) to the farmers. In 2013, some of regencies such as Dompu had Aspiration Funds from Regional House of Representatives and funds from the provincial government to provide incentives for farmers when their cattles were pregnant.

DPRD's Aspiration Funds came from the DPRD's member recess (twice a year). DPRD's members went to their election site, met with the community, and asked the community's aspirations. At that time, one of the aspirations was development assistance of cattle. Furthermore, the Regional House of Representatives (DPRD) assigned the Livestock Office to verify and implement the incentive program for cattle ranchers in certain areas. At this incentive distribution stage, the community was involved in the process of providing the incentive program.

In 2017, in some of the West Nusa Tenggara's regencies such as Dompu, the livestock office regularly conducted monitoring and evaluation twice a year and began conducting workshops for capacity building of dairy farmers. During the monitoring stage, most livestock office only facilitated the difficulties of cattle farmer groups. While supervision was held by the groups themselves. The monitoring activities were only consisted of meeting with the administrators of farmer groups, unable to directly meet the members who received cattle support. The problems expereinced by the farmers were delivered by the group representatives.

The development of corn as a leading commodity was part of agricultural department's roles. The Agricultural Department prepared seed assistance and distributed it through farmer groups which submitted the proposals, as well as the application of cattle provision. The Agricultural department also requested corn seeds to the Ministry of Agriculture. Farmers with 1 hectare land was given 15 kilos of corn seeds but the submission must be through farmer groups to facilitate the assistance process and evaluation monitoring by the counselors. The requirements to join a farmer group was land ownership on their own behalf. Many tenant farmers were difficult to access this assistance. Along with the success of corn harvest at the beginning of PIJAR Program, people who had not joined the farmer groups started to cultivate maize independently without the help from the government. Currently, especially in Dompu Regency, the number of corn fields were increasing.

Table 2. Results of Increased Corn Production of 2008-2017

Source: BPS Dompu, 2018

\begin{tabular}{|l|l|l|}
\hline Year & Harvest area (ha) & Total production (ton) \\
\hline 2008 & 2,312 & 7,196 \\
\hline 2009 & 6,526 & 20,304 \\
\hline 2010 & 5,597 & 29,785 \\
\hline 2011 & 17,240 & 86,200 \\
\hline 2012 & 32.390 & 156.090 \\
\hline 2017 & 81.169 & 604.706 \\
\hline
\end{tabular}


In the earlier years of PIJAR Program, the corn price was low, rarely experiencing price increases. However, due to a visible new income from the corn sector, more people started to cultivate corn. During President Jokowi's visit to Dompu, he listened to the complaints of corn farmers (April 2015). Based on the great potential of corn in Dompu, several months after

president visit, the Ministry of Trade issued a ministerial regulation (Permendag) No. 21 year 2016 about The Stabilization of Corn Reference Price at farmer Level and Permendag No. 63 year 2016 about the Purchase Reference Price at Farmers and Reference Price for Consumers. Since then the welfare of corn farmers had increased along with the certainty of corn prices.

The development of seaweed as one of leading commodities was part oh Fisheries Department roles. Before the implementation of PIJAR Program, seaweed development program was already conducted with funding from the Central Government through CoAdministration Funds (Dana TP). In 2010, the fisheries department was assisted by field counseling officers (PPL) began to help the formation of seaweed farmer groups. PIJAR program assistance was in the form of facilities and seeds through seaweed farmer groups. However, seaweed cultivation especially in Dompu, hade been conducted since 2004.

\section{Stakeholders Support}

PIJAR program was directly and indirectly supported by relevant stakeholders. The first one was cross-sectional cooperation as described above. The second one was indirect supports from private parties, such as (i)existing banks in West Nusa Tenggara such as BRI and NTB bank. They supported the development of community business through people business' credits (kredit usaha rakyat/KUR), so that the cattle ranchers, corn farmers, and seaweed farmers could expand their business through KUR loan application. (ii) corn warehouse as buyer of people corn, for example was PT Seger Agro Nusa. In 2008, PT Seger Agro Nusantara established a brach corn warehouse in Sumbawa. Then in 2011, this company establish a warehouse in Dompu (distributed to Surabaya and exported to the Philippines). So the corn farmers did not find difficulty to sell their crops. (iii) Fisheries Cooperative, this cooperative helped the distribution of seaweed and helped the funding through its savings and loan business. (iv) University support. In 2017, Mataram University and Massey university of New Zealand worked together trough East Indonesia Innovative Farming System and Capability for Agribusiness Activity (IFSCA) to prepare the assistance officers for the cattle groups in West Nusa Tenggara.

\section{CONCLUSION}

Implementation of the PIJAR Program has accommodated local knowledge supported by stakeholders, natural conditions and local context. Provincial government of NTB could find local commodities and local contexts that can be developed to improve the welfare of the community. Local knowledge and context is needed in developing local commodities and requires the cooperation of stakeholders at various levels. Dompu District Government as part of NTB Provincial Government cooperate synergistically to succeed program which proclaimed by Provincial government, so that implementation in Dompu District could prosper society. 


\section{REFERENCES}

Audefroy, J. F., \& Sánchez, B. N. C. (2017). Integrating local knowledge for climate change adaptation in Yucatán, Mexico. International Journal of Sustainable Built Environment, 6(1), 228-237. https://doi.org/10.1016/j.ijsbe.2017.03.007

Ballard, H.L., Fernandez-Gimenez, M.E., Sturtevant, V.E., 2008. Integration of local ecological knowledge and conventional science: a study of seven community- based forestry organizations in the USA. Knowledge and Society 13 (2), 37

BPS Kabupaten Dompu (2018). Dompu dalam Angka. Kabupaten Dompu: BPS

Corburn, Jason. (2003). Bringing Local Knowledge into Environmental Decision Making: Improving Urban Planning for Communities at Risk. Vol 22, Issue 4, pp. 420 - 433. DOI: $10.1177 / 0739456 \times 03022004008$

Giordano, R., Liersch, S., Vurro, M., Hirsch, D., 2010. Integrating local and technical knowledge to support soil salinity monitoring in the Amudarya river basin. Journal of Environmental Management 91, 1718-1729.

Goggin, M.L., Bowman, A.O.M., Lester, J.P., and O’Toole, L.J. Jr (1990). Implementation Theory and Practice: Towards a Third Generation. Glenview, IL: Foreman/Little, Brown.

Jodoin, Sébastien (2017). The Transnational Policy Process for REDD+ and Domestic Policy Entrepreneurship in Developing Countries. Environment and Planning C: Politics and Space, Special Issue on Climate Governance: Entrepreneurs and Entrepreneurship 35(8)1418-1436

Kabupaten Dompu (2012). RKPD Kabupaten Dompu. Pemerintah Kabupaten Dompu

Lawton, A. and Macaulay, M. (2014), Localism in Practice: Investigating Citizen Participation and Good Governance in Local Government Standards of Conduct. Public Admin Rev, 74: 75-83. doi:10.1111/puar.12161

Li, S., Easterby-Smith, M., Lyles, M. A., \& Clark, T. (2016). Tapping the power of local knowledge: A local-global interactive perspective. Journal of World Business, 51(4), 641-653. https://doi.org/10.1016/j.jwb.2016.04.001

Lindblom, Charles E., and David K. Cohen. 1979. Usable knowledge: Social science and social problem solving.NewHaven,CT: Yale Uni- versity Press.

Pratomo, J., Kuffer, M., Martinez, J., \& Kohli, D. (2017). Coupling Uncertainties with Accuracy Assessment in Object-Based Slum Detections, Case Study: Jakarta, Indonesia. Remote sensing, 9(11), [1164]. DOI: 10.3390/rs9111164

Suwarno, A.; van Noordwijk, M.; Weikard, H.-P.; Suyamto, D (2018). Indonesia's forest conversion moratorium assessed with an agent-based model of Land-Use Change and Ecosystem Services (LUCES). Mitigation and Adaptation Strategies for Global Change 23(2): 211-229 DOI: 10.1007/s11027-016-9721-0

Van der Ploeg, Jan D. 1993. Potatoes and knowledge. In An anthropological critique of development: The growth of ignorance, edited by Mark Hobart, 209-29. London: Routledge. 